\title{
Нові підходи до розробки комплексних методів цивільної безпеки
}

\section{Сергій Азаров А; Михайло Дівізінюк ${ }^{\text {B }}$; Валентина Лобойченко ${ }^{\text {C; }}$ Володимир Мірненко ${ }^{D}$; Роман Шевченко ${ }^{\mathrm{E}}$}

Received: May 30, 2020 | Revised: June 16, 2020 | Accepted: June 30, 2020

DOI: $10.33445 /$ sds.2020.10.3.5

\begin{abstract}
Анотація
В досліджені розглянуто проблема розробки комплексних методів попередження надзвичайних ситуацій з накопичувальним та імпульсним негативним впливом наслідків на стан довкілля, які за своєю природою відносяться до кола задач спільної проблематики наукових напрямків цивільного захисту та екологічної безпеки. 3 метою вирішення поставленої задачі послідовно розглянуті широке коло пов'язаних між собою завдань, які дозволили в рамках існуючих світових підходів щодо формування методології наукових досліджень в області швидко прогресуючих сфер природнотехногенно-соціального середовища, дослідити процес діалектичної трансформації поля проблематики цивільної безпеки, визначити основні ї̈ етапи та характерні умови. Останнє дало змогу визначити логічні зв'язки, які дозволили суттєво зменшити наявні методологічні розбіжності спеціальних методів окремих наукових напрямків та однозначно узгодити у подальшому вибір групи методів з доказу достовірності отриманих результатів в межах застосування шуканих комплексних методів. Це дозволило: по-перше, розробити загальні підходи з дослідження задач спільного кола проблематики наукових напрямків цивільного захисту та екологічної безпеки та визначити основні логічні функціональні та часові зв'язки комплексних методів попередження надзвичайних ситуацій з накопичувальним та імпульсним впливом на стан довкілля; по-друге, на прикладі аналізу небезпеки технологічного процесу хімічних підприємств малотоннажного виробництва розробити структуру комплексного методу 3 оцінки та попередження надзвичайних ситуацій з накопичувальним та імпульсним впливом на стан довкілля, який композиційно складається з функціональних елементів спеціальних методів наукових напрямків цивільний захист та екологічна безпека, які поєднані прямими та зворотними функціональними і часовими зв'язками.
\end{abstract}

Ключові слова: комплексні методи, попередження надзвичайних ситуацій, вплив на стан довкілля.

\section{Постановка проблеми}

Цивільний захист (ЦЗ), як і низка сучасних наукових напрямків, що отримали поштовх у своєму розвитку в останнє десятиріччя, на жаль не має стійкої методологічної основи. Здебільш методологія ЦЗ $€$ запозиченою 3 інших суміжних напрямків, а від так попре наявних внутрішніх методологічних протиріч наукових напрямків - “донорів" додаються протиріччя

\footnotetext{
А Інститут ядерних досліджень НАН України, Україна, провідний науковий співробітник, д.т.н., с.н.c., e-mail: azarovsi@i.ua, ORCID: 0000-0002-9109-8714

в Інститут геохімії та навколишнього середовища НАН України, Україна, завідувач відділом, д.ф-м., професор, е-mail: divizinyuk@ukr.net, ORCID: 0000-0002-5657-2302

с Національний університет цивільного захисту України, доцент, к.х.н., с.н.с., е-mail: vloboichm@gmail.com, ORCID: 0000-0001-5188-6479

D Національний університет оборони імені Івана Черняховського, завідувач кафедри, Заслужений працівник освіти України, д.т.н., професор, e -mail:mirnenkovi@gmail.com, ORCID: 0000-0002-7484-1035

Е Національний університет цивільного захисту України, начальник наукового відділу, д.т.н., с.н.c., e-mail: shevchenko605@i.ua, ORCID: 00000001-9634-6943
} 
синергетичного характеру унаслідок складних процесів їх творчого поєднання в рамках визначення об'єкту дослідження ЦЗ. 3 іншого боку накопичення досліджень прикладного характеру у сфері ЦЗ, проведення щорічного їх обговорення в рамках постійно діючих Міжнародних та Всеукраїнських наукових конференцій вимагає проведення системо формуючих досліджень, які направлені, насамперед, на знятяя інформаційно- комунікативних бар'єрів серед фахівців наукової спільноти з напрямку ЦЗ.

Таким чином на сьогодні існує актуальна проблема сфери ЦЗ з розробки комплексних методів ЦЗ, які формується у ході синергетичного поєднання базових принципів синектики, морфології, спеціальних методів цивільної безпеки (ЦБ) та розглядають складну проблематику яка одночасно входить до складу декількох суміжних її напрямків.

\section{Аналіз останніх досліджень та публікацій}

Сучасні наукові дослідження з напрямку формування методологічних аспектів умовно можна поділити на дві досить не рівнозначні, за обсягом накопиченого матеріалу, частини. До першої, слід віднести пласт досліджень де розглядаються загальні та загально наукові методи наукового пізнання [1; 2] та їх практичне застосування в контексті проведення наукових досліджень [3, 4], формування синтактизу [5; 6] та інших методологічних характеристик кваліфікаційних наукових робіт [7; 8]. 3 іншого боку маємо дослідження в яких розглядаються окремі методологічні аспекти при вирішенні безпосередньо різнопланових задач ЦЗ, як-то, наприклад, попередження НC на об'єктах критичної інфраструктури [9; 10], попередження НС в інформаційному просторі [11; 12], попередження НС природного характеру [13; 14], попередження НС унаслідок хімічної небезпеки [15] та пожежі [16] на потенційнонебезпечних об'єктах. У підсумку це дало змогу досить однозначно визначити методологічні аспекти спеціальних методів наукового напрямку ЦЗ [17]. В той же час методи “часткової" групи [3], які покликані розглядати питання проблематики, що одночасно входять до поля двох та більшого числа суміжних напрямків сфери ЦБ, одним з яких (базовим 3 погляду формуючих особливостей) $є$ ЦЗ на сьогодні увага не приділялась. Відсутність досліджень 3 цього питання породжує принаймні дві ключові методологічні проблеми, які суттєво гальмують прогрес наукових досліджень в галузі ЦБ. По-перше, це відсутність діалектичного ланцюга який логічно поєднував би загальні та загально наукові методи наукових досліджень зі спеціальними методами ЦЗ. По-друге, їх відсутність примушує науковців чітко розмежовувати суміжну дослідницьку сферу ЦБ між конкретними науковими напрямками, що у більшості випадків не йде на користь якості кінцевого наукового результату та супроводжується методологічними непорозуміннями.

Таким чином, нагальним на часі $є$ розробка комплексних методів “часткової" групи 3 дослідження процесів забезпечення безпеки хімічно-небезпечних підприємств малотонажного виробництва, як новий підхід до вирішення складної задачі спільного кола проблематики наукових напрямків цивільного захисту та екологічної безпеки.

\section{Постановка завдання}

Метою роботи $€$ розробка комплексних методів попередження надзвичайних ситуацій на хімічно-небезпечних підприємствах малотонажного виробництва 3 накопичувальним та імпульсним негативним впливом її наслідків на стан довкілля.
Для досягнення мети роботи необхідно вирішити наступні взаємопов'язані задачі:

1. Дослідити трансформацію методів дослідження цивільної безпеки з розгляду задач, які одночасно входить до складу декількох суміжних її наукових напрямків. 
2. Розробити загальні підходи до 3. Розробити структуру комплексного формування комплексних методів 3 методу попередження надзвичайних ситуацій дослідження задач спільного кола з накопичувальним та імпульсним негативним проблематики наукових напрямків цивільний впливом ї̈ наслідків на стан довкілля на захист та екологічна безпека. прикладі технологічного процесу хімічних підприємств малотоннажного виробництва.

\section{Виклад основного матеріалу}

Виходячи із загальновживаного визначення методу наукового дослідження як сукупності спеціальних прийомів, норм, правил, процедур, що регламентують процес пізнання і забезпечують рішення дослідницької задачі [3], діалектику взаємозв'язку методів наукового дослідження можливо представити у вигляді схеми їх трансформації вздовж відповідної вісі діалектичної трансформації (ДТ), яка наведена на мал. 1.

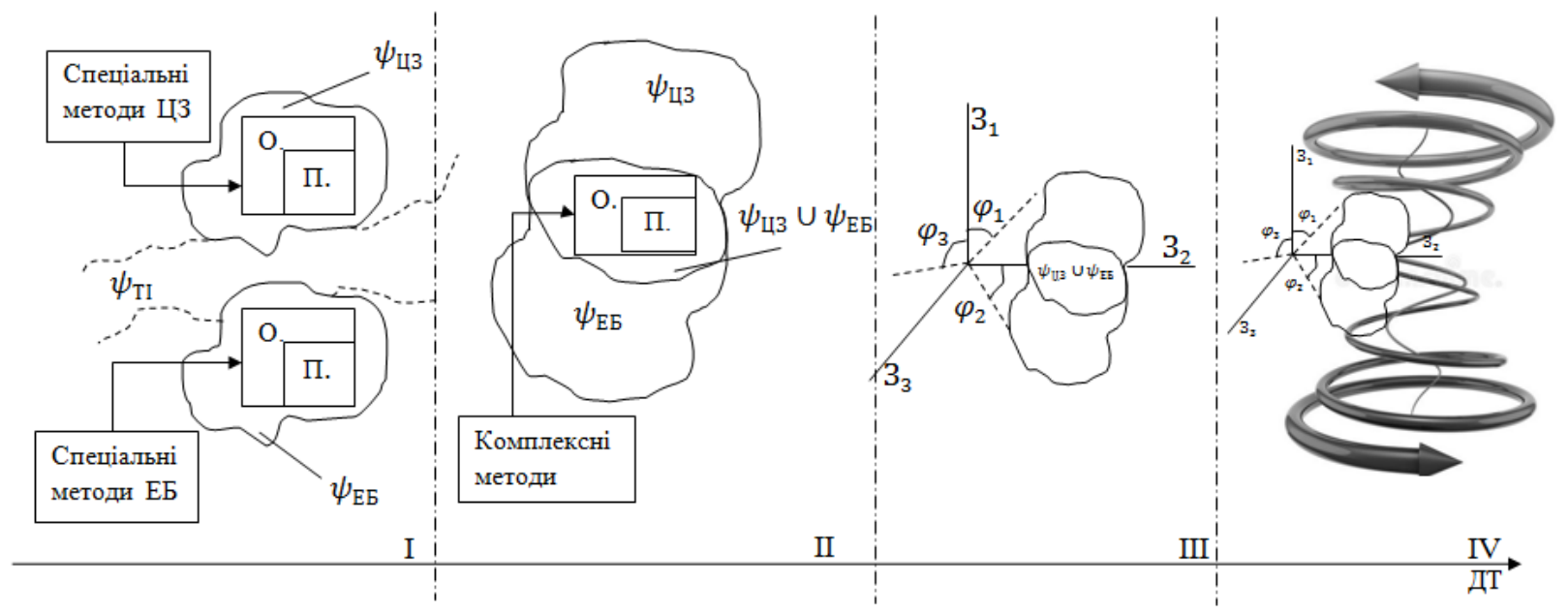

Мал. 1. Схема взаємозв'язку методів наукового дослідження у сфері ЦБ.

На мал. 1 відповідна трансформація взаємозв'язку методів наукового дослідження в сфері ЦБ відбувається за якісною віссю діалектичної трансформації у чотири етапи.

І етап - конкретизація поля проблематики цивільної безпеки за науковими напрямками $\left(\psi_{ц з}\right)$ - цивільний захист, $\left(\psi_{\text {ЕБ}}\right)$ - екологічна безпека. На цьому етапі методологічне обмеження щодо приналежності об'єкту (О.) та предмету (П.) наукового дослідження конкретній області наукового напрямку (1):

$$
\begin{aligned}
& \text { П. } \in \text { O. } \in \psi_{ц 3} ; \\
& \text { або } \\
& \text { П. } \in \text { O. } \in \psi_{\text {ЕБ}} .
\end{aligned}
$$

Відповідно і вплив на предмет та об'єкт дослідження з боку дослідника відбувається в межах спеціальних методів відповідного наукового напрямку.
II етап - визначення суміжного поля проблематики цивільного захисту та екологічної безпеки, що фактично значно зменшує площину (terra incognito) невизначеності $\left(\psi_{\mathrm{TI}}\right)$ та узгоджує методологічне протиріччя I етапу (ДТ). На цьому етапі фактично вирішується методологічне обмеження (1) та виникає умова доцільності існування комплексних методів наукового дослідження в сфері ЦБ (2):

$$
\text { П. } \in \text { O. } \in \psi_{\text {Цз }} \cup \psi_{\text {ЕБ }} \text {. }
$$

Відповідно і вплив на предмет та об'єкт дослідження з боку науковця відбувається в межах комплексних методів.

III етап - визначення умов нахилу площини дослідження В сфері ЦБ В просторі загальнонаукових методів дослідження відповідно до класифікації, яка наведена на мал. 2. 


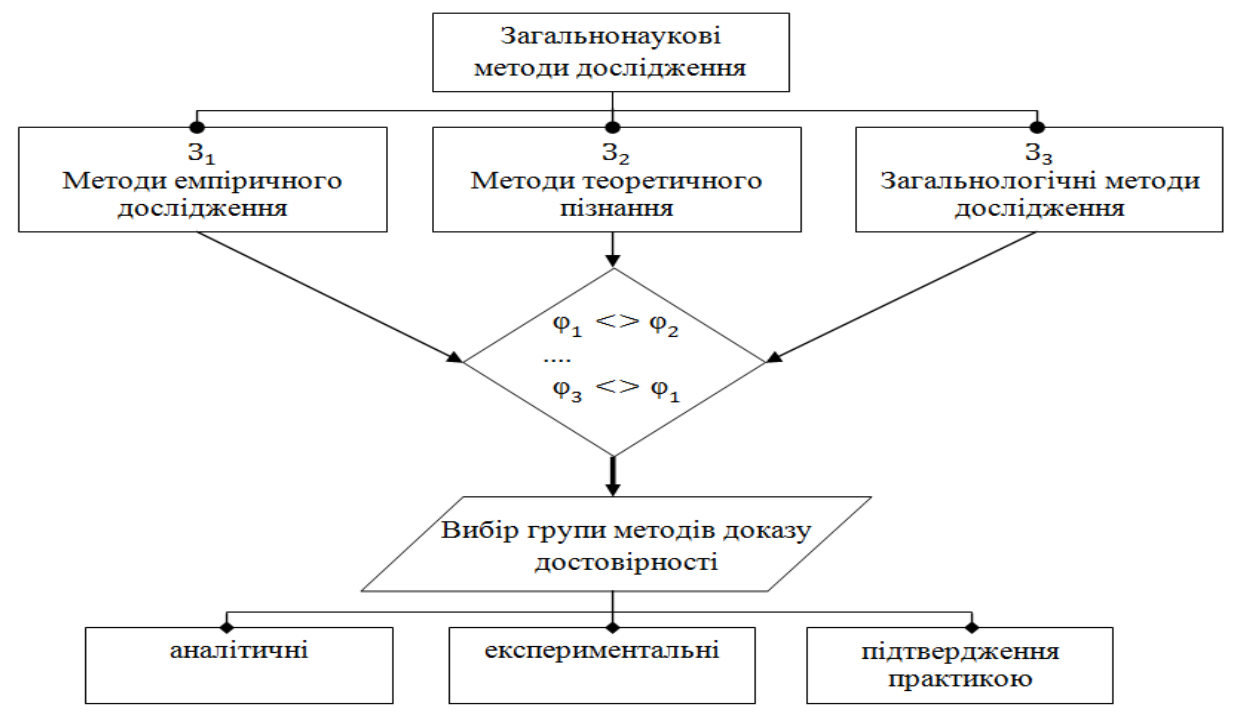

Мал. 2. Схема розвитку III етапу ДТ методів наукового дослідження у сфері ЦБ.

Відповідно варіація умовних кутів нахилу проекції площини дослідження $\left(\varphi_{1}, \varphi_{2}, \varphi_{3}\right)$ визначає доцільність подальшого застосування однієї з груп методів доказу достовірності результатів, отриманих за використання комплексних методів.

IV етап - визначення напрямку та способу мислення, який відбувається в рамках прийнятої філософської концепції формування співвідношення "безпека-небезпека" в рамках парадигми "цивільний безпека". Механізм формування поточного концепту безпеки та їі часова зміна на ведені на мал. 3. та більш детально розглянута в роботі [18].



Мал. 3. Схема діалектичної зміни концепту формування та зміни функціонального поля ЦБ. 
Де $\mathrm{F}_{\mathrm{C}}$ - рівень обізнаності 3 питань формування та функціонування поля ЦБ у тому числі і суміжних областях знань.

Схема (мал. 3) вмішує умови двох типів, а саме: $\mathrm{C}_{\mathrm{B}}^{\mathrm{R}}$ - умови вибору концепту формування поля ЦБ в площині основних формуючих параметрів $\left(\Psi^{\{. .\}}\right)$та $\mathrm{C}_{\mathrm{A}}^{\mathrm{R}}$ - умови вибору концепту в площині додаткових параметрів $\left(\Psi^{\{. .\},\{.\}}\right) . \quad$ Особливостями запропонованої схеми $€$ можливість розгляду варіантів концепту нижчого рівня у процесі вибору на більш просунутих шаблях шкали обізнаності. Такий підхід, з одного боку, забезпечує високий рівень організаційної наступності та впровадження інноваційних технологій і підходів, з іншого формує резерв функціональних рішень та напрями подальшого вдосконалення поля ЦБ, як в площині основних параметрів так i в площинах додаткових параметрів, зазвичай, із залученням досліджень у сфері суміжних знань.

Слід зазначити, що площини основних та додаткових параметрів $€$ постійно змінними, в наслідок розвитку нашої уяви щодо процесів контролю їх взаємозв' язку та впливу зовнішніх умов. Умови вибору $\mathrm{C}_{\mathrm{B}}^{\mathrm{R}}$ та $\mathrm{C}_{\mathrm{A}}^{\mathrm{R}}$ не $\epsilon$ умовами оптимального типу. $\mathrm{y}$ даному випадку мова йде, насамперед, про сприятливість реалізації концепту виходячи 3 технологічних, економічних, законодавчоправових, фізіологічних та інших, як основних так і додаткових можливостей.

В межах визначеної (ДТ) вісі, процес формування комплексних (часткових) методів наукового дослідження відбувається на II етапі та базується на спеціалізованих методах, з одного боку, наукового напрямку Ц3 (мал. 4), з іншого - наукового напрямку ЕБ (мал.5).

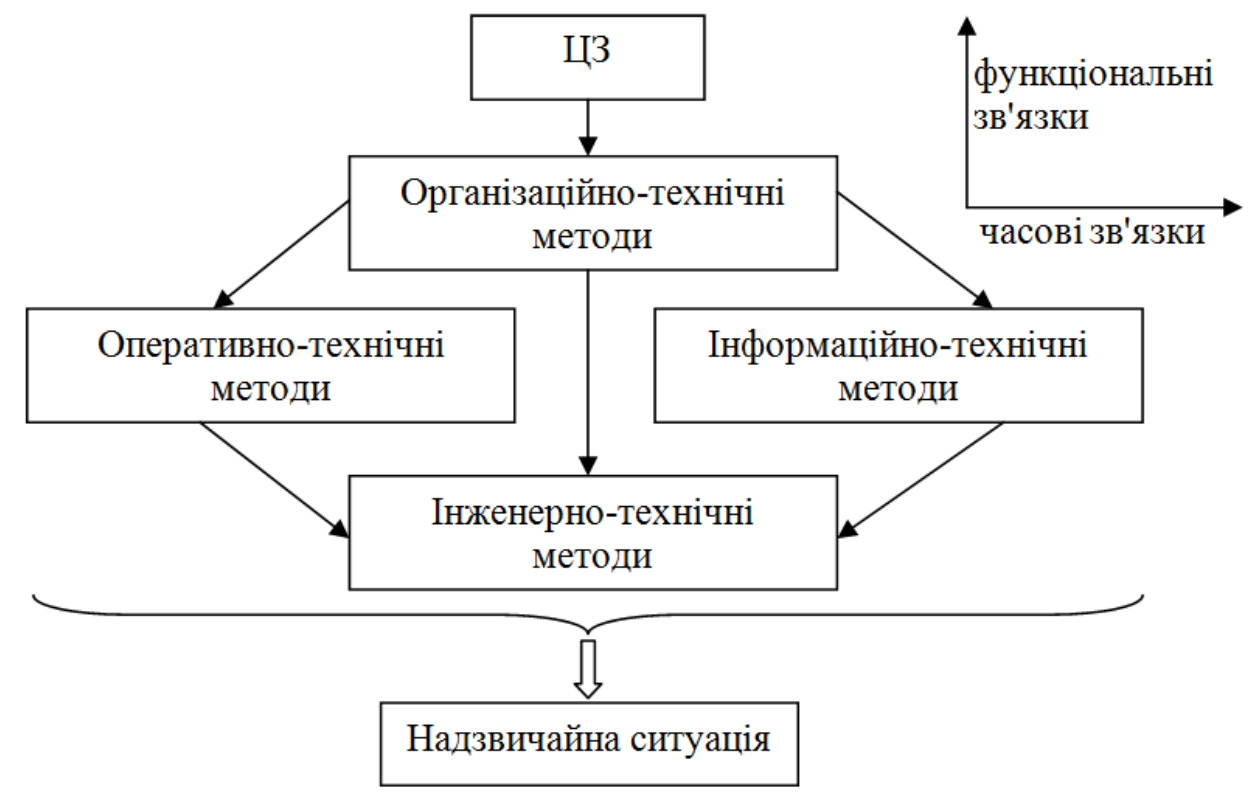

Мал. 4. Схема формування спеціальних методів наукового напрямку цивільний захист 




Мал. 5. Схема формування спеціальних методів наукового напрямку екологічна безпека.

Як бачимо, що попре деяку подобу методологічних структур. Схема формування спеціальних методів наукового напрямку цЗ не містить зв'язків часового характеру, а від так з одного боку $€$ більш універсальною щодо можливості її застосування для різних етапів дослідження процесів розвитку та протидії небезпеки, з іншого боку потребує додаткового визначення часових меж застосування спеціальних методів (мал. 6).

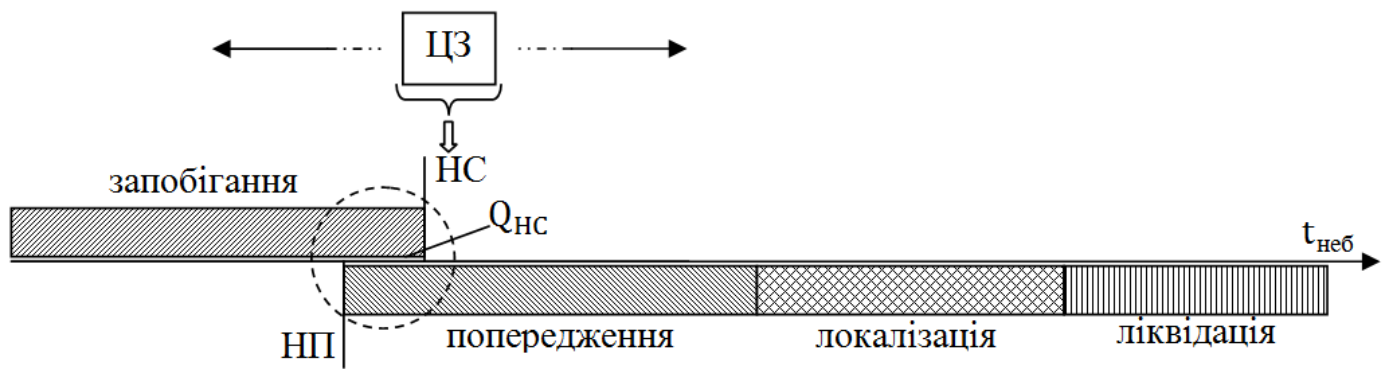

Мал. 6. Часове визначення меж застосування спеціальних методів наукового напрямку цЗ.

На сьогодні складним та досить суперечливим аспектом наведеної методологічної структури $€$ невизначеність зони переходу $\mathrm{Q}_{\mathrm{HC}}$ на межі виникнення $\mathrm{HC}$ з часу виникнення небезпечної події (НП).

Законодавча невизначеність стану НП в рамках парадигми ЦЗ примушує дослідників вводити штучні обмеження щодо часу існування стану НП на кшталт ( $\left.\mathrm{t}_{\text {неб }}^{\mathrm{H \Pi}} \rightarrow 0\right)$ тощо. В той же час наведене методологічне обмеження логічно вирішується в рамках трактування $\mathrm{HC}$, як умовної межі, що визначається виходячи із співвідношення наявної небезпеки та можливостями щодо її протидії. А від так маємо динамічно змінну характеристику ключового поняття "надзвичайна ситуація" парадигми цивільний захист, що фактично унеможливлює застосування наведеної методологічної структури мал. 4 в рамках парадигми “екологічна безпека".

Відповідно схема формування спеціальних методів наукового напрямку ЕБ вміщує як функціональні, так і часові зв'язки. Така структура $€$ менш уніфікованою та потребує застосування при вирішенні завдань поля проблематики сфери ЕБ послідовно всього комплексу спеціальних методів. Різниця при 
цьому полягає лише у відсотку їх присутності у формуванні кінцевого результату рішення задачі, а від так і форма кінцевого результату (прогноз, оцінка, зниження рівня) цілковито залежить від домінуючого спеціального методу (мал. 5) наукового напрямку ЕБ.

Наявна різниця в структурах формування спеціальних методів наукових досліджень цЗ та ЕБ породжує протиріччя узгодженості умовних кутів нахилу площин дослідження

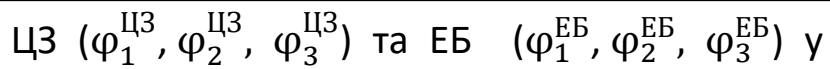
вигляді (3):

$$
\varphi_{1}^{Ц З ~} \neq \varphi_{1}^{\mathrm{EБ}} ; \varphi_{2}^{Ц З ~} \neq \varphi_{2}^{\mathrm{EБ}} ; \varphi_{3}^{Ц З ~} \neq \varphi_{3}^{\mathrm{EБ}} .
$$

Узгодженість умовних кутів можливо досягти у разі застосування наступного часового припущення, яке графічно зображено на мал. 7.

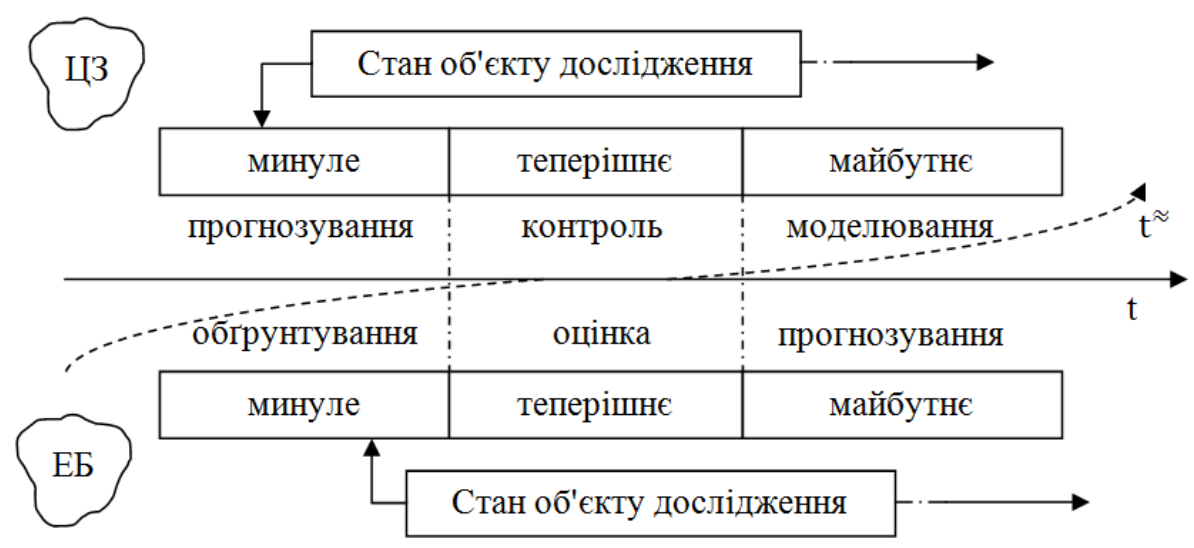

Мал. 7. Структура часового підходу до узгодженості умовних кутів нахилу площин дослідження наукових напрямків ЦЗ та ЕБ.

Такий підхід передбачає узгодження умовних кутів нахилу площини дослідження у разі розгляду стану об'єкту дослідження в минулому в бік умовних кутів наукового напрямку ЕБ, за пріоритетним нахилом викривлення часової вісі $(\mathrm{t} \approx)$, у разі дослідження стану об'єкту в майбутньому в бік умовних кутів наукового напрямку ЦЗ, та фактичним нехтуванням різниці під час розгляду теперішнього стану об'єкту дослідження.

Враховуючи вищенаведене загальні підходи до проведення наукового дослідження в суміжній області пошуку проблематики наукових напрямків ЦЗ та ЕБ приведена на мал. 8.

Організація наукового дослідження у суміжній області пошуку розпочинається 3 вирішення складного завдання синектичного характеру щодо визначення проблеми, яка відповідає умові (2) за об'єктом та предметом дослідження. Послідовно на даному етапі вирішуються питання часового узгодження умовних кутів нахилу площин дослідження та формуються загальні рекомендації щодо формату та структури комплексних методів дослідження проблеми. На другому етапі організації наукового дослідження формується коло завдань, які в достатній мірі описують хід пошуку відповіді на проблемне питання в контексті комплексних методів дослідження. Сукупність рішень окремих задач складають проект пошуку відповіді на проблемне питання, яке надалі досліджується на етапі морфологічного аналізу з метою структуризації та уніфікації, на базі комплексного аналізу, з можливістю застосування отриманих результатів для широкого кола проблемних питань відповідної суміжної області наукових напрямків. Заключний етап формування шуканої методології - фахове обговорення в рамках рецензування уніфікованого проекту. 


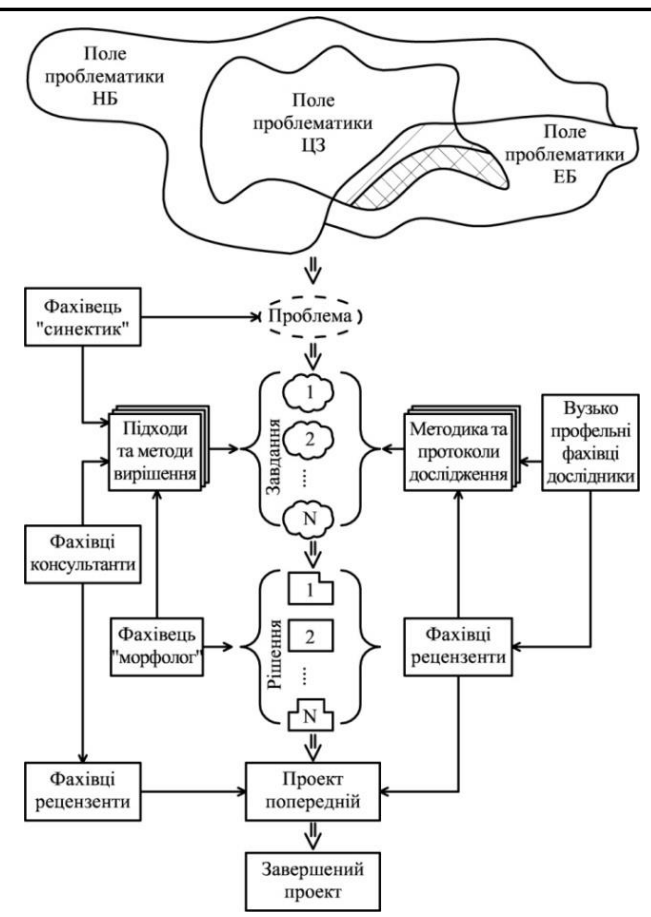

Мал. 8. Схема організації творчого колективу та наукового дослідження в суміжній області пошуку проблематики наукових напрямків ЦЗ та ЕБ.

Головною зазначеного негативних наслідків впливу технологічного методологічного підходу $\epsilon$ можливість процесу хімічних підприємств малотонажного внесення обгрунтованих змін у функціональні характеристики комплексних методів на всіх етапах організації та проведення наукового дослідження в суміжній області пошуку.

Застосовуючи наведений методологічний підхід (мал. 8), на прикладі дослідження виробництва (ХПМВ), розроблена структура комплексного інженерно-технічного методу 3 оцінки та попередження надзвичайних ситуацій з накопичувальним та імпульсним негативним впливом на стан довкілля, яка наведена на мал. 9.

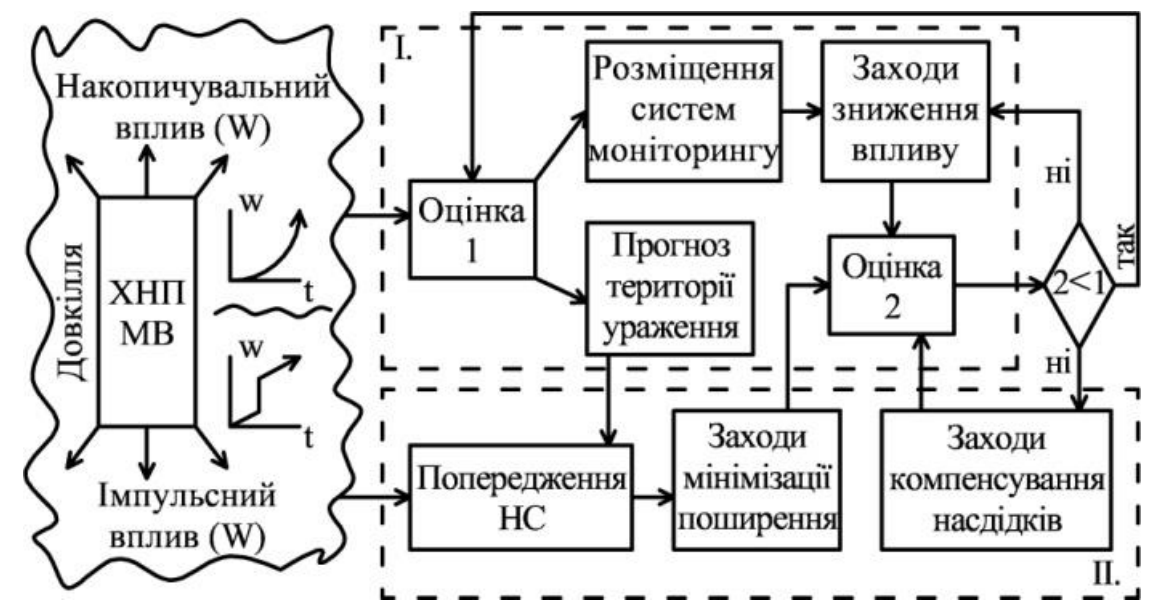

Мал. 9. Структура комплексного інженерно-технічного методу з оцінки та попередження $\mathrm{HC}$ на ХНПМВ з накопичувальним та імпульсним негативним впливом на стан довкілля. 
Композиційно наведена структура складається з елементів спеціальних методів обох наукових напрямків, які поєднані прямими та зворотними функціональними та часовими зв'язками, що дозволяє цілковито виконати як умову (2), так і узгодити невизначеність умовних кутів в рамках проведення подальшого дослідження.

\section{Висновки}

В роботі запропоновано новий підхід до формування комплексних ("часткових") методів попередження надзвичайних ситуацій з накопичувальним та імпульсним негативним впливом їі наслідків на стан довкілля, що $\epsilon$ завданням кола проблематики одночасно двох наукових напрямків цивільного захисту та екологічної безпеки.

1. В рамках існуючих світових підходів щодо формування методології наукових досліджень в області швидко прогресуючих сфер природно-техногенно-соціального середовища, розглянуто процес діалектичної трансформації поля проблематики цивільної безпеки. Визначені основні етапи трансформації та їх характерні умови. Побудовані логічні зв'язки, які дозволили суттєо зменшити наявні методологічні розбіжності спеціальних методів окремих наукових напрямків та однозначно узгодити в подальшому вибір групи методів з доказу достовірності отриманих результатів в межах застосування комплексних методів.
2.Розроблені загальні підходи 3 дослідження задач спільного кола проблематики наукових напрямків цивільного захисту та екологічної безпеки, які дозволили визначити основні логічні функціональні та часові зв'язки комплексних методів попередження надзвичайних ситуацій 3 накопичувальним та імпульсним впливом на стан довкілля.

3. На прикладі дослідження небезпеки технологічного процесу хімічних підприємств малотоннажного виробництва розроблено структуру комплексного методу оцінки та попередження надзвичайних ситуацій 3 накопичувальним та імпульсним впливом на стан довкілля, який композиційно складається 3 функціональних елементів спеціальних методів наукових напрямків цивільний захист та екологічна безпека, які поєднані прямими та зворотними функціональними і часовими зв'язками.

\section{Список використаних джерел}

1. Lebedev S. A. Methodology of science and scientific knowledge levels. European Journal of Philosophical Research. 2014. № 1(1). C.6572

2. Blachowicz, J., 2009, "How science textbooks treat scientific method: A philosopher's perspective", The British Journal for the Philosophy of Science, 60(2): 303-344.

3. Важинський С. Е., Щербак Т. І. Методика та організація наукових досліджень: навч. посіб. / Суми. СумДПУ ім. А. С. Макаренко. 2016. 260 c.

4. Зацерковний В. І., Тішаєв І. В. Демидов В. К. Методологія наукових досліджень: навч. посіб. / Ніжин. НДУ ім. М.Гоголя. 2017. 236 с.

5. Чорний І. В., Перцова В. А., Гололич І. М. Методологія дисертаційного дослідження.
Мовні особливості наукового стилю. /Харків. ХНУВС. 2019. 272 c.

6. Дептрьова К. В. Основи теорії мовної комунікації: навчально-методичний посібник. / Полтава: ПНПУ ім. В.Г. Короленка. 2012. 70 с.

7. Гуторов О.І. Методологія а організація наукових досліджень: навч. посіб. / Харків: XHAУ. 2017. 272 c.

8. Сурмін Ю.П. Наукові тексти: специфіка, підготовка та презентація. / Київ: НАДУ. 2008. $184 \mathrm{c}$.

9. Азаренко Е., Гончаренко Ю., Дивизинюк М., Мирненко В., Сирица Ю. Структурнологическая модель управления чрезвычайной ситуацией террористического характера $и$ ее особенности, обусловленные скрытым электромагнит- 
ным воздействием на оперативный состав охраняемого объекта критической инфраструктуры. Journal of Scientific Papers "Social Development and Security". 2020. 10 (1). 177-187.

10. Азаренко Е., Гончаренко Ю., Дивизинюк М., Мирненко В., Сирица Ю., Олиферук В. Процесс развития чрезвычайной ситуации на охраняемом объекте критической инфраструктуры. Journal of Scientific Papers "Social Development and Security". 2019. 9 (6). 132-146.

11. Шевченко Р. І. Інформаційно-функціональний аналіз системи моніторингу та прогнозування надзвичайних ситуацій. Системи обробки інформації. - Харків: Харківський університет Повітряних Сил імені Івана Кожедуба, 2015. Вип. 8 (133). - С. $148-157$.

12. Азаренко Е. В., Гончаренко Ю. Ю., Дивизинюк М. М., Ковач В. Е. Чрезвычайные ситуации, обусловленные информационными потоками. Правове, нормативне та метрологічне забезпечення системи захисту інформації в Україні. 2015. Вип.2. C. $21-25$.

13. Бабарика І. Г., Єременко С. А., Кривулькін І. М., Лєвтєров О. А., Шевченко Р.І. Розвиток інноваційних методів скорочення наслідків надзвичайних ситуацій природного характеру. Проблеми надзвичайних ситуацій. Харків: НУЦЗУ. 2018. Вип. 28. С. 2738.
14. Azarov S., Mashkov V., Shevchenko R., Shcherbak S. Methodology for the ecological environmental impact assessment of the forest fire consequences under complex radiation conditions of fire load. Scientific and technical journal "Technogenic and Ecological Safety», 7(1/2020). P. 22-26.

15. Стрілець В. В., Шевченко Р. І. Формування початкових та граничних умов термічної локалізації осередку надзвичайної ситуації, пов'язаної з ураженням хімічно-небезпечними речовинами. Науково-технічний збірник "Комунальне господарство міст». Серія: Технічні науки та архітектура. Харків : ХНАМГ. 2020, №154. С. 293-297.

16. Лєвтєров О. А. Розробка математичної моделі попередження надзвичайних ситуацій унаслідок пожежі 3 осередком виникнення зовні потенційно-небезпечного об'єкту. Комунальне господарство міст, 2019, 6(152), 233-238.

17. Дівізінюк М. М., Азаренко О. В., Шевченко Р. І. Проблемні питання та шляхи уніфікації понятивного апарату парадигми цивільний захист. / Розвиток цивільного захисту в сучасних безпекових умовах: Матеріали 21 Всеукраїнської НПК (за міжнародною участю), Київ: ІДУЦЗ, 2019. С. 102-103.

18. Прокопенко О. В., Шевченко Р. І. Методика ресурсно-критичного управління заходами попередження надзвичайних ситуацій медико-біологічного характеру. / Проблеми надзвичайних ситуацій. Харків: НУЦЗУ. 2020. Вип. 31. С. 42-59.

\title{
Новые подходы к разработке комплексных методов гражданской безопасности
}

\author{
Сергей Азаров А; Михаил Дивизинюк ${ }^{\text {; }}$; Валентина Лобойченко ${ }^{\text {; }}$ \\ Владимир Мирненко ${ }^{D}$; Роман Шевченко ${ }^{\mathrm{E}}$

\footnotetext{
А Институт ядерных исследований НАН Украины, ведущий научный сотрудник, д.т.н., с.н.c., e-mail: azarovsi@i.ua В Институт геохимии и окружающей среди НАН Украины, заведующий отделом, д.ф-м., профеccop, e-mail: divizinyuk@ukr.net,

С Национальный университет гражданской защиты Украины, доцент, к.х.н., с.н.c., e-mail: vloboichm@gmail.com,

D Национальный университет оборони Украины имени Ивана Черняховского, заведующий кафедрой д.т.н., профессор, e -mail: mirnenkovi@gmail.com
} \\ E Национальный университет гражданской защиты Украины, начальник научного отдела, д.т.н., с.н.c., e-mail: shevchenko605@i.ua
}




\begin{abstract}
Аннотация
В исследовании рассмотрены проблема разработки комплексных методов предупреждения чрезвычайных ситуаций с накопительным и импульсным негативным влиянием последствий на состояние окружающей среды, которые по своей природе относятся к кругу задач совместной проблематики научных направлений гражданской защиты и экологической безопасности. С целью решения поставленной задачи последовательно рассмотрены широкий круг связанных между собой задач, которые позволили в рамках существующих мировых подходов по формированию методологии научных исследований в области быстро прогрессирующих областей природнотехногенно-социальной среды, исследовать процесс диалектической трансформации поля проблематики гражданской безопасности, определить основные ее этапы и характерные условия. Последнее позволило определить логические связи, которые позволили существенно уменьшить имеющиеся методологические разногласия специальных методов отдельных научных направлений и однозначно согласовать в дальнейшем выбор группы методов с доказательства достоверности полученных результатов в рамках применения искомых комплексных методов. Это позволило: вопервых, разработать общие подходы по исследованию задач общего круга проблематики научных направлений гражданской защиты и экологической безопасности и определить основные логические функциональные и временные связи комплексных методов предупреждения чрезвычайных ситуаций с накопительным и импульсным воздействием на состояние окружающей среды; во-вторых, на примере анализа опасности технологического процесса химических предприятий малотоннажного производства разработать структуру комплексного метода оценки и предупреждения чрезвычайных ситуаций с накопительным и импульсным воздействием на состояние окружающей среды, который композиционно состоит из функциональных элементов специальных методов научных направлений гражданской защите и экологическая безопасность, которые объединены прямыми и обратными функциональными и временными связями.
\end{abstract}

ключевые слова: комплексные методы, предупреждения чрезвычайных ситуаций, влияние на состояние окружающей среды.

\title{
New approaches to the development of integrated methods of civil security
}

\author{
Sergiy Azarov ${ }^{\text {A }}$; Mykhailo Divizinyuk ${ }^{\text {; }}$ Valrntina Loboichenko ${ }^{\text {; }}$; \\ Volodymyr Mirnenko ${ }^{D}$; Roman Shevchenko ${ }^{\mathrm{E}}$ \\ A Institute for Nuclear Research NAS of Ukraine, e-mail: azarovsi@i.ua \\ B Institute of Environmental Geochemistry of the NAS of Ukraine, e-mail: divizinyuk@ukr.net \\ C National University of Civil Defence of Ukraine, PhD, Senior Researcher, e-mail: vloboichm@gmail.com \\ D The National Defence University of Ukraine named after Ivan Cherniakhovskyi, e-mail: mirnenkovi@gmail.com \\ E National University of Civil Defence of Ukraine, Doctor of Technical Sciences, Senior Researcher, e-mail: shevchenko605@i.ua
}

\begin{abstract}
The problem of development of complex methods of prevention of emergencies with cumulative and impulse negative impact on the state of the environment, which by their nature belong to the range of tasks of common problems of scientific directions of civil protection and ecological safety, is considered in the research. In order to solve this problem, a wide range of related tasks have been consistently considered, which allowed within the existing global approaches to the formation of research methodology in the field of rapidly advancing spheres of natural and man-made social environment, to investigate the process of dialectical transformation of civil security. its main stages and characteristic conditions. The
\end{abstract}


latter made it possible to identify logical connections that significantly reduced the existing methodological differences of special methods of certain scientific areas and unambiguously agree on the choice of a group of methods to prove the reliability of the results within the application of the required complex methods. This allowed: first, to develop general approaches to the study of common problems of scientific areas of civil protection and environmental safety and to determine the main logical functional and temporal links of complex methods of emergency prevention with cumulative and impulse impact on the environment; secondly, to develop the structure of a comprehensive method for assessing and preventing emergencies with cumulative and impulse impact on the environment, which consists of functional elements of special methods of scientific directions of civil protection and environmental safety, which combined with direct and inverse functional and temporal connections.

Keywords: complex methods, emergency prevention, impact on the environment.

\section{References}

1. Lebedev S.A. (2014). Methodology of science and scientific knowledge levels. European Journal of Philosophical Research. № 1(1). S.65-72

2. Blachowicz, J., (2009). "How science textbooks treat scientific method: A philosopher's perspective", The British Journal for the Philosophy of Science, 60(2): 303-344.

3. Vazhinskij S. E., Sherbak T. I.(2016). Metodika ta organizaciya naukovih doslidzhen: navch. posib. / Sumi. SumDPU im. A.S. Makarenko. $260 \mathrm{~s}$.

4. Zacerkovnij V. I., Tishayev I. V. Demidov V. K. (2017). Metodologiya naukovih doslidzhen: navch. posib. / Nizhin. NDU im. M. Gogolya. $236 \mathrm{~s}$.

5. Chornij I. V., Percova V. A., Gololich I. M. (2019). Metodologiya disertacijnogo doslidzhennya. Movni osoblivosti naukovogo stilyu. /Harkiv. HNUVS. $272 \mathrm{~s}$.

6. Degtyarova K. V. (2012). Osnovi teoriyi movnoyi komunikaciyi: navchalnometodichnij posibnik. / Poltava: PNPU im. V.G. Korolenka. $70 \mathrm{~s}$.

7. Gutorov O.I. (2017). Metodologiya a organizaciya naukovih doslidzhen: navch. posib. / Harkiv: HNAU. $272 \mathrm{~s}$.

8. Surmin Yu.P. (2008). Naukovi teksti: specifika, pidgotovka ta prezentaciya. / Kyiv: NADU. $184 \mathrm{~s}$.

9. Azarenko E., Goncharenko Yu., Divizinyuk M., Mirnenko V., Sirica Yu. (2020). Strukturnologicheskaya model upravleniya chrezvychajnoj situaciej terroristicheskogo haraktera i ee osobennosti, obuslovlennye skrytym elektromagnitnym vozdejstviem na operativnyj sostav ohranyaemogo obekta kriticheskoj infrastruktury. Journal of Scientific Papers "Social Development and Security". 10 (1). 177-187.

10. Azarenko E., Goncharenko Yu., Divizinyuk M., Mirnenko V., Sirica Yu., Oliferuk V. (2019). Process razvitiya chrezvychajnoj situacii na ohranyaemom obekte kriticheskoj infrastruktury. Journal of Scientific Papers "Social Development and Security". 9 (6). 132146.

11. Shevchenko R.I. (2015). Informacijnofunkcionalnij analiz sistemi monitoringu ta prognozuvannya nadzvichajnih situacij. Sistemi obrobki informaciyi. - Kharkiv: Harkivskij universitet Povitryanih Sil imeni Ivana Kozheduba, Vip. 8 (133). - S. 148 - 157.

12. Azarenko E.V., Goncharenko Yu.Yu., Divizinyuk M.M., Kovach V.E. (2015). Chrezvychajnye situacii, obuslovlennye informacionnymi potokami. Pravove, normativne ta metrologichne zabezpechennya sistemi zahistu informaciyi $v$ Ukrayini. Vip.2. - S. $21-25$.

13. Babarika I. G., Yeremenko S. A., Krivulkin I. M., Lyevtyerov O. A., Shevchenko R.I. (2018). Rozvitok innovacijnih metodiv skorochennya naslidkiv nadzvichajnih situacij prirodnogo harakteru. Problemi nadzvichajnih situacij. Kharkiv: NUCZU. Vip. 28. S. 27-38. 
14. Azarov S., Mashkov V., Shevchenko R., Shcherbak S. (2020). Methodology for the ecological environmental impact assessment of the forest fire consequences under complex radiation conditions of fire load. Scientific and technical journal "Technogenic and Ecological Safety», 7(1). R. 22-26.

15. Strilec V.V., Shevchenko R.I. (2020). Formuvannya pochatkovih ta granichnih umov termichnoyi lokalizaciyi oseredku nadzvichajnoyi situaciyi, pov'yazanoyi z urazhennyam himichno-nebezpechnimi rechovinami. / Naukovo-tehnichnij zbirnik «Komunalne gospodarstvo mist». Seriya: Tehnichni nauki ta arhitektura. Kharkiv: HNAMG. №154. S. 293-297.

16. Lyevtyerov O. A. (2019). Rozrobka matematichnoyi modeli poperedzhennya nadzvichajnih situacij unaslidok pozhezhi z oseredkom viniknennya zovni potencijnonebezpechnogo ob'yektu. Komunalne gospodarstvo mist, 6(152). 233-238.

17. Divizinyuk M.M., Azarenko O.V., Shevchenko R.I. (2019). Problemni pitannya ta shlyahi unifikaciyi ponyativnogo aparatu paradigmi civilnij zahist. / Rozvitok civilnogo zahistu v suchasnih bezpekovih umovah: Materiali 21 Vseukrayinskoyi NPK (za mizhnarodnoyu uchastyu), Kiyiv: IDUCZ. S. 102-103.

18. Prokopenko O.V., Shevchenko R.I. (2020). Metodika resursno-kritichnogo upravlinnya zahodami poperedzhennya nadzvichajnih situacij mediko-biologichnogo harakteru. Problemi nadzvichajnih situacij. Kharkiv: NUCZU. Vip. 31. S. 42-59. 